\title{
Pseudorabies Virus: A Highly Specific Transneuronal Cell Body Marker in the Sympathetic Nervous System
}

\author{
A. M. Strack and A. D. Loewy \\ Department of Anatomy and Neurobiology, Washington University School of Medicine, St. Louis, Missouri 63110
}

\begin{abstract}
The present report presents a series of experiments using Bartha's K strain of pseudorabies virus (PRV) designed to test the specificity of this virus as a retrograde transneuronal marker in the sympathetic nervous system of rats. Three experiments were performed. First, an injection of PRV was made in the anterior chamber of the eye, followed $24 \mathrm{hr}$ later by an injection of WGA-HRP. PRV infected neurons in the superior cervical ganglion (SCG) always contained WGAHRP. This dual labeling of SCG neurons suggests that the PRV cell body labeling does not nonspecifically infect nearby neurons. Second, after PRV injections into the pinna or eye, a specific segmental distribution of the transneuronal cell body labeling occurred in the intermediolateral cell column and related spinal areas. After eye injections, the majority of transneuronally labeled neurons were in the T1-T3 segments. After pinna injections, the majority of labeled cells were in the T2-T5 segments. Since the SCG cells innervating these 2 end organs lie in close proximity to each other within the ganglion, these results suggest that a specific transfer of the virus to the preganglionic neurons occurred, possibly via a transsynaptic mechanism. Third, virally infected glial cells were rarely found in the SCG or spinal cord. In summary, Bartha's K strain of PRV is a specific transneuronal retrograde marker in the sympathetic nervous system.
\end{abstract}

In 1938, Sabin developed a bioassay to study whether particular classes of viruses infect the nervous system (Sabin, 1938). This assay involved instilling a suspension of viruses into the nasal cavity of mice and then, after an appropriate survival period, analyzing the trigeminal and autonomic ganglia that innervate the nasal mucosa for neuropathological changes that accompany viral infection. In addition, the CNS of these animals was also studied to determine if transneuronal viral infections had occurred. He found that in some CNS sites, such as the spinal trigeminal nucleus, superior salivatory nucleus, and intermediolateral cell column (IML), second-order neurons were transneuronally infected. While this assay was designed to screen various types of viruses for their neuroinfectivity, this was the

\footnotetext{
Received Dec. 5, 1989; revised Jan. 29, 1990; accepted Feb. 1, 1990.

This work was supported by the National Institute of Heart, Lung, and Blood of the National Institutes of Health (HL 25449). A.M.S. is supported by the McDonnell Center for the Studies of Higher Brain Function. We thank Dr. K. Platt for supplying us with pseudorabies viruses and antibodies, William B. Sawyer and Xay Van Nguyen for technical assistance, and Jeff Lichtman for constructive comments.

Correspondence should be addressed to Dr. A. D. Loewy, Box 8108, Department of Anatomy and Neurobiology, Washington University School of Medicine, 660 S. Euclid Avenue, St. Louis, MO 63110.

Copyright (C) 1990 Society for Neuroscience $0270-6474 / 90 / 072139-09 \$ 03.00 / 0$
}

first direct indication that certain viruses are capable of infecting specific chains of functionally related neurons.

Interest in using viruses as a potential neuroanatomical tool remained dormant for more than 4 decades until Kristensson and his coworkers (1982) presented evidence that herpes simplex virus could be used as a transneuronal cell body marker. Martin and Dolivo (1983) were the first investigators to make systematic use of the transneuronal viral labeling method for neuroanatomical studies. Since then, other groups have applied this method to study CNS pathways, and various neurotropic viruses have been used, including pseudorabies virus (Martin and Dolivo, 1983; Rouiller et al., 1986, 1989; Strack et al., 1989a, b), herpes simplex virus 1 (Irie et al., 1987, 1989; Ugolini et al., 1987, 1989; Thomander et al., 1988; Norgren and Lehman, 1989; McLean et al., 1989; Wessclingh ct al., 1989), and rabies virus (Kucera et al., 1985).

The major advantage of using viruses as transneuronal markers over other markers such as WGA-HRP (see Spatz, 1989, for references) or tetanus toxin C-fragment (e.g., Evinger and Erichson, 1986) is their ability to replicate within the neuron and thus function as a self-amplifying cell marker. This property ensures a high signal, which allows for easy detection using standard immunohistochemical procedures. Another major advantage of using viruses as retrograde transneuronal cell body markers is that they can be detected with a dual immunohistochemical procedure that allows one to detect neuropeptides or transmitter enzymes in virally infected neurons (Strack et al., 1989a, b; Spencer et al., 1990). Thus, this procedure can be used to study the neuroanatomical connections of specific chemically coded central neurons. Because of the latter reason, our laboratory has been particularly interested in determining whether viruses will act as specific transneuronal cell body markers.

Of the various available neurotropic viruses, pseudorabies virus (PRV) appears to be one of the best candidates for a transneuronal viral marker because humans are resistant to it (Gustafson, 1975; cf. Mravik et al., 1987). Thus, there is minimal risk to laboratory workers, but since PRV infects a wide spectrum of mammals, care must be taken to ensure that animal colonies do not become infected (Gustafson, 1975). This risk is probably reduced with Bartha's K strain of PRV, which is an attenuated virus that is used routinely to immunize pigs and cattle (Platt et al., 1979).

The central issue regarding the usefulness of the retrograde transneuronal viral method hinges on whether the transfer of viruses occurs by a specific transsynaptic mecharism or by lateral spread via some type of nonsynaptic mechanism (Fig. 1). Latcral viral spread could produce infections in nearby neurons or glial cells or uptake by nearby, but unrelated, axonal endings. 


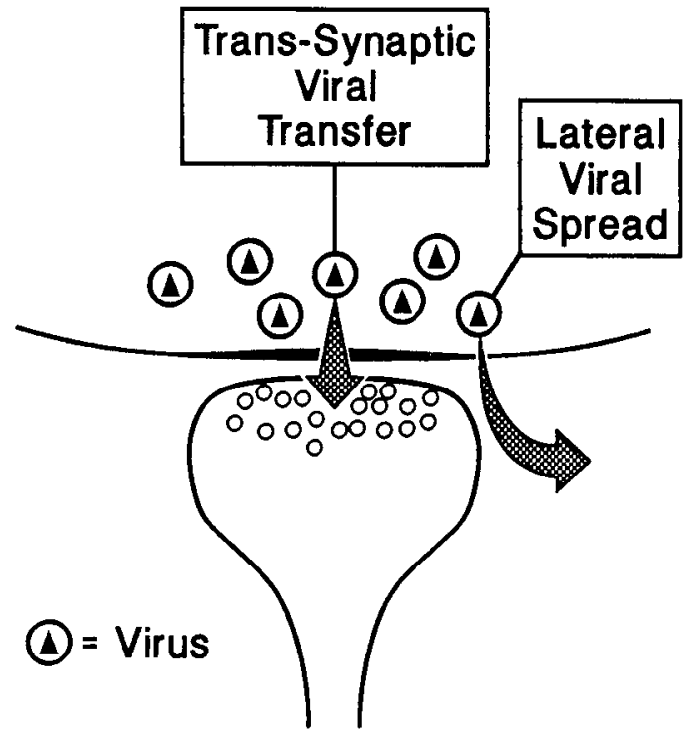

Figure 1. Schematic drawing of 2 potential routes of transneuronal viral transfer in the nervous system.

If the infection became disseminated in this manner, specificity of viral transfer in functionally related chains of neurons would be lost. Rigorous demonstration of the actual mechanism is an extremely difficult task. Even if electron microscopic evidence is produced showing viral particles in the synapses abutting on infected neurons, this would not eliminate the possibility that infected neurons shed viruses in the nearby neuropil and nearby cells took up the virus and transferred it across synapses (see Fig. 7C).

The superior cervical ganglion (SCG) is an excellent site to test for the specificity of viral transfer because the ganglion cells are organized in a nontopographic fashion, but thcy reccivc segmental inputs from sympathetic preganglionic neurons which are topographically organized. Because the neural pathways of the SCG were already well worked out by electrophysiological techniques, we used this system to test the accuracy or the retrograde transneuronal viral labeling method.

In this paper, we have used several experimental paradigms to determine whether PRV is taken up by nearby, but unrelated, neuronal cell bodies or synapses, or by glial cells. We demonstrate here that Bartha's K strain of PRV can be used for a specific retrograde transneuronal cell labeling marker in the sympathetic nervous system. Our results strongly argue that the viruses are transferred at synaptic sites.

\section{Materials and Methods}

$S C G$ as a test site for transneuronal viral transport experiments. The SCG was chosen as a test site for some of the present transneuronal transport experiments because the sympathetic neurons are arranged in a nontopographic manner in the ganglion (Lichtman et al., 1979), but the preganglionic inputs to these cells arise from specific spinal segments (Langley, 1892; Njà and Purves, 1977; Lichtman et al., 1979). Thus, if specific patterns of transneuronal cell body labeling occurred in the sympathetic preganglionic nuclei after injecting different target organs of the head, a strong case for specificity of viral transport could be made.

Prior to beginning our studies on viral specificity, we verified the nontopographic arrangement of SCG cells by doing a series of dual retrograde tracer injections (Fig. 2). Male Sprague-Dawley rats (80-100 $\mathrm{gm}$, Sasco, O'Fallon, MO, $n=4$ ) were anesthetized with sodium pentobarbital $(50 \mathrm{mg} / \mathrm{kg})$. Five $10 \mu \mathrm{l}$ injections of a $4 \%$ solution of Fast blue in $\mathrm{H}_{2} \mathrm{O}$ were made subcutaneously in the left pinna. Then, in the

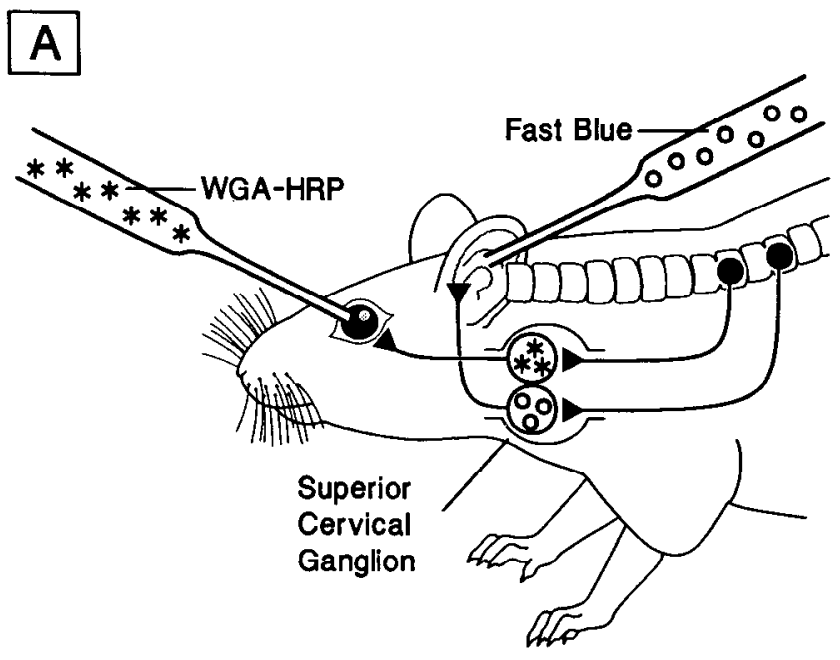

B FB 374, Left Superior Cervical Ganglion

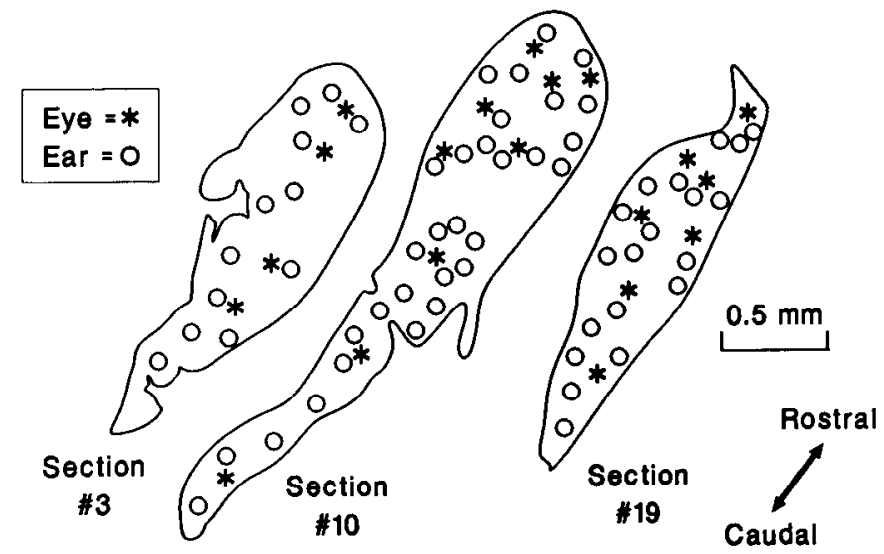

Figure 2. A, Diagram of a retrograde transport experiment designed to examine the topography of cells in the SCG that innervate the eye and pinna. $B$, Drawings of 3 sections of the SCG showing the pattern of cell body labeling seen after Fast blue injections in the pinna and a WGA-HRP injection into the anterior chamber of the eye. 0,8 Fast blue-containing ganglion cells; *, 4 WGA-HRP labeled cells.

same rat, $5 \mu \mathrm{l}$ of $2.5 \% \mathrm{WGA}-\mathrm{HRP}$ in saline was injected into the anterior chamber of the left eye. Three days later, the rats were reanesthetized and perfused intracardially with saline followed by $4 \%$ paraformaldehyde in $0.1 \mathrm{~m}$ sodium phosphate buffer ( $\mathrm{pH} 7.4)$. Both SCGs were removed, placed in $30 \%$ sucrose for $2 \mathrm{~d}$ or more, and then cut at 10 $\mu \mathrm{m}$ on a cryostat. The sections were mounted on glass slides as a 1-in3 series. One set of sections was incubated overnight at $4^{\circ} \mathrm{C}$ with $1: 400$ goat anti-WGA antibody (Vector Labs, Burlingame, CA) and 10\% rabbit serum in potassium phosphate buffer (KPBS, pH 7.4). After 2 KPBS rinses, they were then reacted for $2 \mathrm{hr}$ with $1: 100$ biotinylated rabbit anti-goat IgG (Vector Labs, Burlingamc, CA) in $10 \%$ rabbit serum and KPBS. After 2 rinses, the tissue was then reacted with 1:100 fluorescein isothiocyanate (FITC)-conjugated streptavidin (Jackson Labs, West Grove, PA) in KPBS for $2 \mathrm{hr}$. After 2 more rinses, the tissues were allowed to dry and were coverslipped using a glycerol-PBS mountant (Citifluor, London). The SCGs were examined and representative sections mapped using an $X-Y$ plotter attached to an MD1 microscope digitizer (Minnesota Datametrics Corp., St. Paul, MN).

Experiment 1: specificity of PRV uptake by cell bodies. In order to examine whether SCG cells near the PRV retrogradely labeled neurons became nonspecifically infected, sequential injections of PRV and WGA- 


\section{SEQUENTIAL EYE EXPERIMENT}
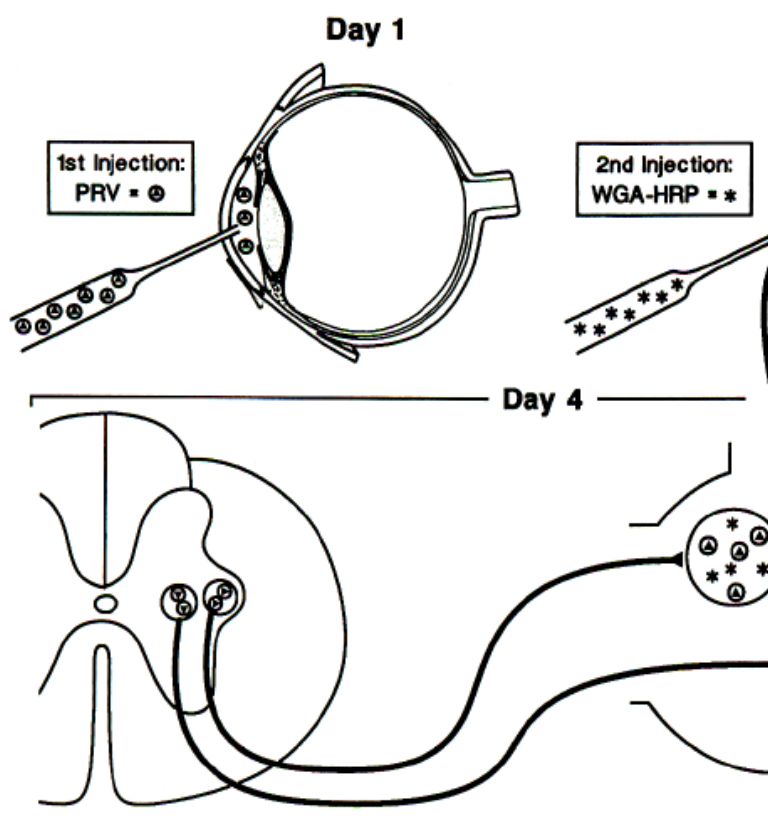

Day 4

\section{Day 2}
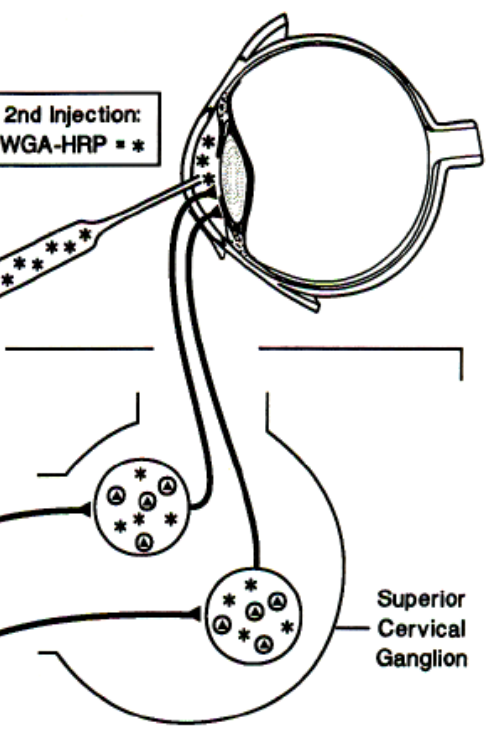

Figure 3. Experiment 1: Schematic diagram illustrating the experimental paradigm of the sequential retrograde cell body labeling experiment.
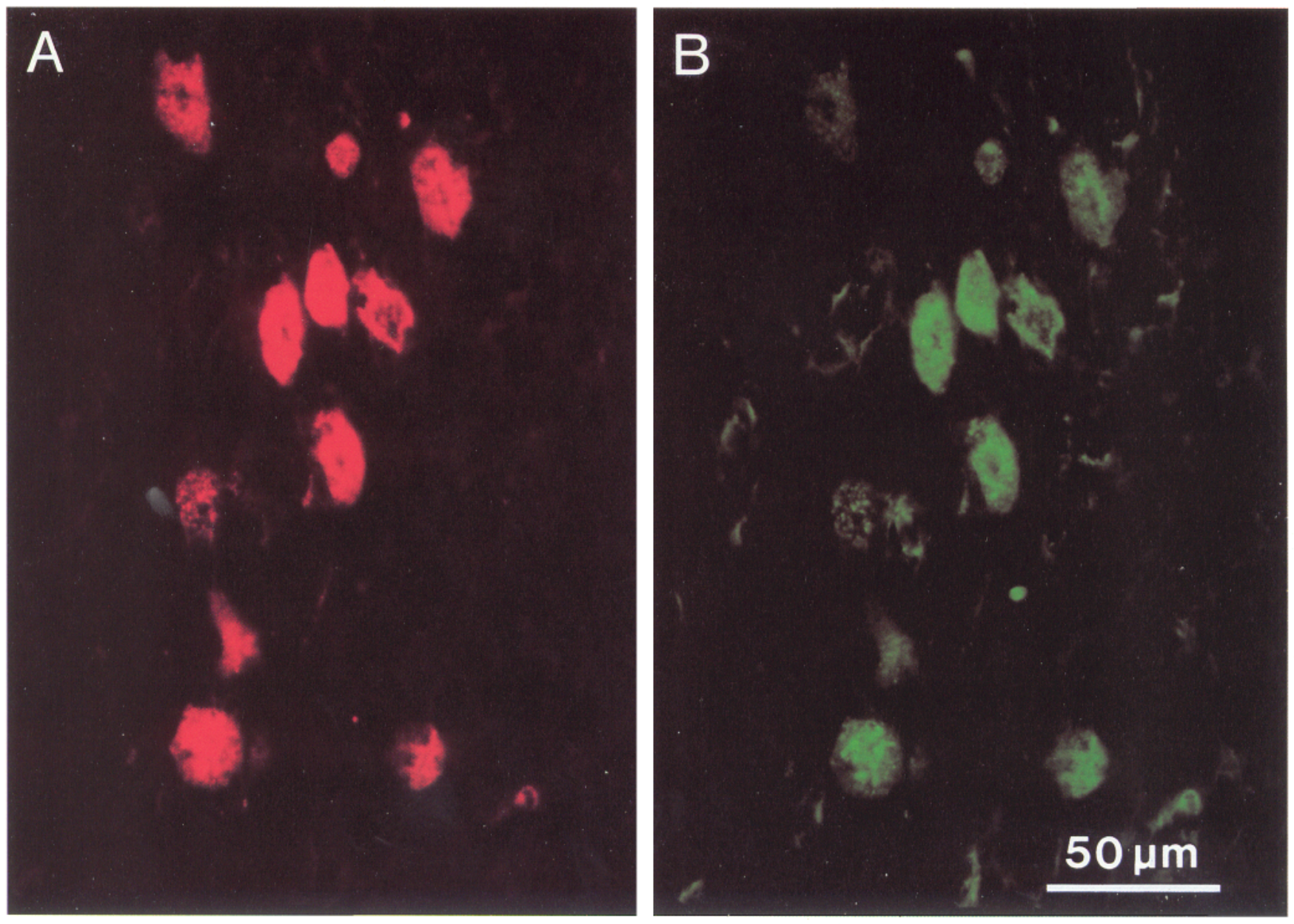

Figure 4. Photomicrographs illustrating $(A)$ PRV-infected SCG cells and $(B)$ WGA-HRP retrogradely labeled SCG neurons. Note that both retrograde cell markers are present in the same cells, indicating that PRV retrogradely labels neurons in a specific manner. Scale bar, $50 \mu \mathrm{m}$. 
Figure 5. Experiment 2: This experiment was designed to test whether injections into different end organs of the head resulted in cell body labeling of specific spinal segments. If nonspecific viral uptake had occurred in the SCG, the 2 histograms would be identical.
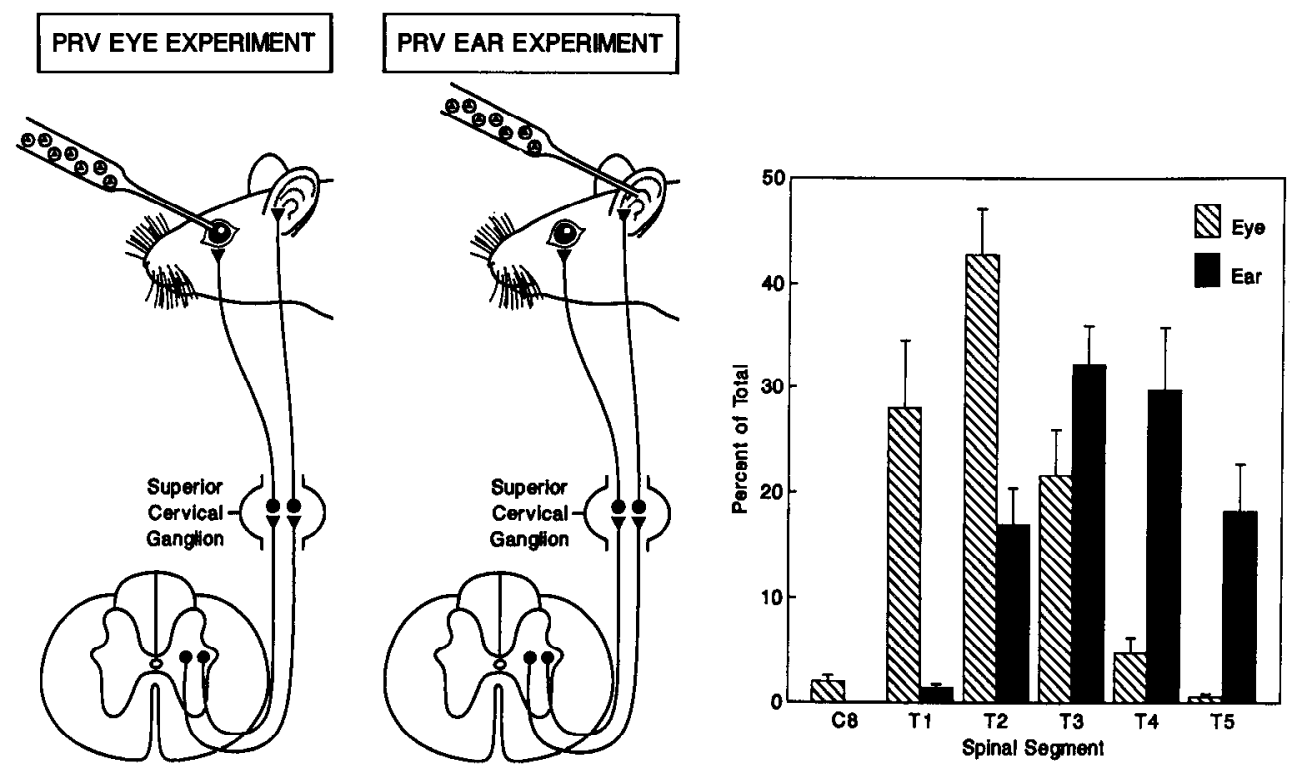

HRP were made in the anterior chamber of the eye (Figs. 3,4 ). Under general anesthesia, the left eye of 12 rats was injected with $10 \mu \mathrm{l}$ Bartha's $\mathrm{K}$ strain of PRV [titer $=2 \times 10^{5}$ plaque-forming units $(\mathrm{pfu}) / \mathrm{ml}$ ]. One day later, the same eye was injected with $10 \mu 1$ of a $2.5 \%$ suspension of WGA-HRP in saline. On the 4th day, the rats were perfused as described above. The SCGs and spinal cords were removed and stored in 30\% sucrose for $2 \mathrm{~d}$ before processing.

The SCGs were processed for the simultaneous demonstration of PRV and WGA immunoreactivity in the same section. Cryostat sections were cut at $10 \mu \mathrm{m}$, mounted on gelatin-coated slides, and reacted overnight at $4^{\circ} \mathrm{C}$ with an antibody solution containing $1: 400$ goat anti-WGA (Vector Labs, Burlingame, CA), 1:1000 pig anti-PRV (NC332), and 10\% rabbit serum in KPBS. The following day, after 2 rinses with KPBS, the sections were reacted with 1:100 biotinylated rabbit anti-goat IgG and $10 \%$ rabbit serum in KPBS for $2 \mathrm{hr}$ at room temperature. After 2 $\mathrm{hr}$, the sections were again rinsed and reacted with 1:100 FITC-conjugated streptavidin, 1:50 rhodamine isothiocyanate (RITC)-conjugated rabbit anti-pig IgG (Zymed, San Francisco, CA), and 10\% rabbit serum in KPBS for $2 \mathrm{hr}$ at room temperature. The sections were then rinsed, allowed to dry, and coverslipped.

The spinal cords were examined for PRV immunoreactivity. Tissue blocks containing 3 spinal segments (viz., C8-T2, T3-T5) were cut at $50 \mu \mathrm{m}$ in the horizontal plane on a freezing microtome. The sections were reacted with a 1:5000 dilution of a pig polyclonal PRV antibody (NC332). The antibody was visualized with an avidin-biotin-horseradish peroxidase complex $(\mathrm{ABC})$ using a Vectastain $\mathrm{ABC}$ kit purchased from Vector Laboratories (Burlingame, $\mathrm{CA}$ ). The sections were mounted on gelatin-coated slides and coverslipped using DPX mountant $\mathrm{BDH}$, Poole, U.K.). Controls using a preimmune serum (NC474) were found to be negative (Strack et al., $1989 \mathrm{a}, \mathrm{b}$ ).

Experiment 2: specificity of $P R V$ uptake by synapses. To test whether there was nonspecific synaptic uptake of the virus by neurons innervating the SCG, PRV injections into different target organs were made. A comparison was made between the transneuronal spinal cord labeling seen after PRV injections in the eye or the pinna (Figs. 5, 6). For the eye injections, $10 \mu \mathrm{PRV}$ was injected into the anterior chamber $(n=$ 10 ; titer $=2 \times 10^{5} \mathrm{pfu} / \mathrm{ml}$ ). For the ear injections, five $10 \mu \mathrm{l}$ injections were placed subcutaneously in the left pinna of 5 rats.

Four days postinjection, the rats were perfused as above. The spinal cords and the SCGs were removed and processed by the ABC method. Cell counts were done of a 1 -in-2 series for each segment in the spinal cord for the C8-T5 segments (Table 1). The quantitative data were plotted as histograms (Fig. 5).

Experiment 3: PRV infections of glial cells. The SCGs and spinal cords from PRV-infected rats were examined using a dual immunohistochemistry procedure to study whether glial cells become infected with PRV. Glial fibrillary acidic protein (GFAP) was used as a marker for fibrous astrocytes and galactocerebroside was used as a marker for Schwann cells and oligodendroglia.

For GFAP and PRV labeling, the sections were incubated overnight at $4^{\circ} \mathrm{C}$ in 1:500 mouse anti-GFAP (BioGenex Lab, Dublin, CA) and 1:1000 pig anti-PRV (NC332) in KPBS. After 2 rinses in KPBS, the sections were incubated for $2 \mathrm{hr}$ in 1:100 biotinylated horse anti-mouse IgG (Vector Labs, Burlingame, CA) in KPBS, rinsed twice in KPBS, then incubated for $2 \mathrm{hr}$ in 1:100 FITC-streptavidin, 1:50 RITC rabbit anti-pig IgG (Zymed, San Francisco, CA) for $2 \mathrm{hr}$, then rinsed, mounted, allowed to dry, and coverslipped with Citifluor mountant.

Tissues were placed directly in ascites fluid of a mouse monoclonal antibody to galactocerebroside (Ranshat et al., 1982) with 1:1000 pig anti-PRV (NC332) overnight at $4^{\circ} \mathrm{C}$. The slides were then rinsed in $\mathrm{KPBS}$, and the protocol used for the secondary antibody staining was the same as that of dual GFAP and PRV staining.

\section{Results}

We first established that the ganglion cells of the SCG are organized in a nontopographic fashion confirming Lichtman et al. (1979). Figure $2 B$ illustrates the results of a typical experiment. The sympathetic ganglion cells that innervate the pinna and iris lie in close proximity to each other in the SCG in a nontopographic arrangement. While the ganglion cells are arranged in a nontopographic fashion within the SCG, they receive inputs from sympathetic preganglionic neurons that originate from specific spinal segments (Njá and Purves, 1977; Lichtman et al., 1979). This pattern makes the SCG an excellent site to test for specificity of viral transfer. In this system, any virus disseminating from retrogradely infected ganglion cells in a nonspecific way could be taken up by inappropriate neurons or synapses from identifiable populations of neurons.

Figure 6. Photomicrographs of horizontal sections through the C8-T2 spinal segments illustrating the pattern of retrograde transneuronal cell body labeling in the IML after PRV injections into the anterior chamber of the eye $(A)$ and pinna $(B)$. Note that in $B$ there are very few labeled cells. Scale bar, $100 \mu \mathrm{m}$. 

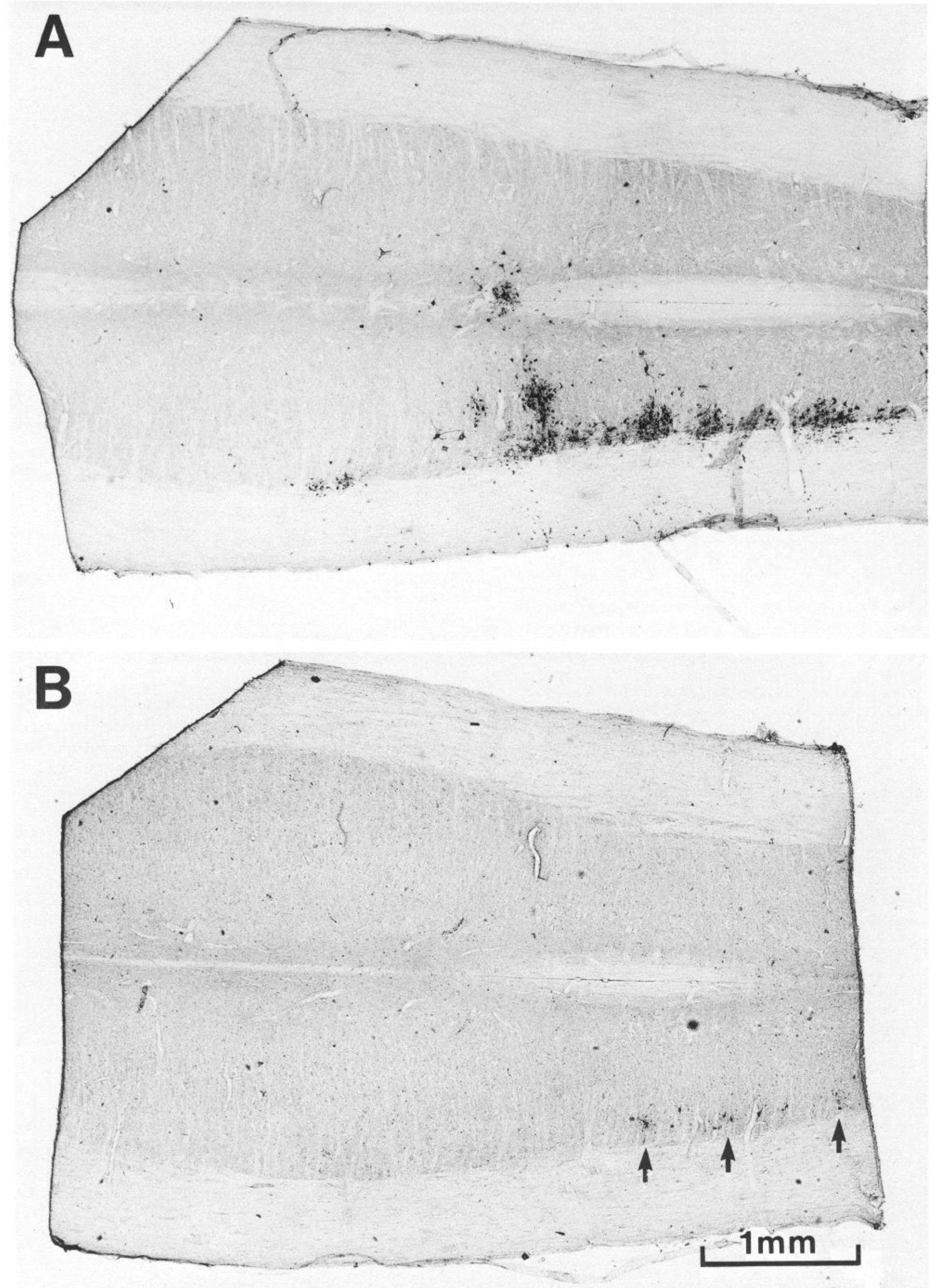
Figure 7. $A$ and $B$, General scheme of retrograde and retrograde transneuronal labeling in the sympathetic nervous system. $C$ and $D$, Drawings showing the potential sites of lateral viral spread that would produce false-positive cell body labeling.
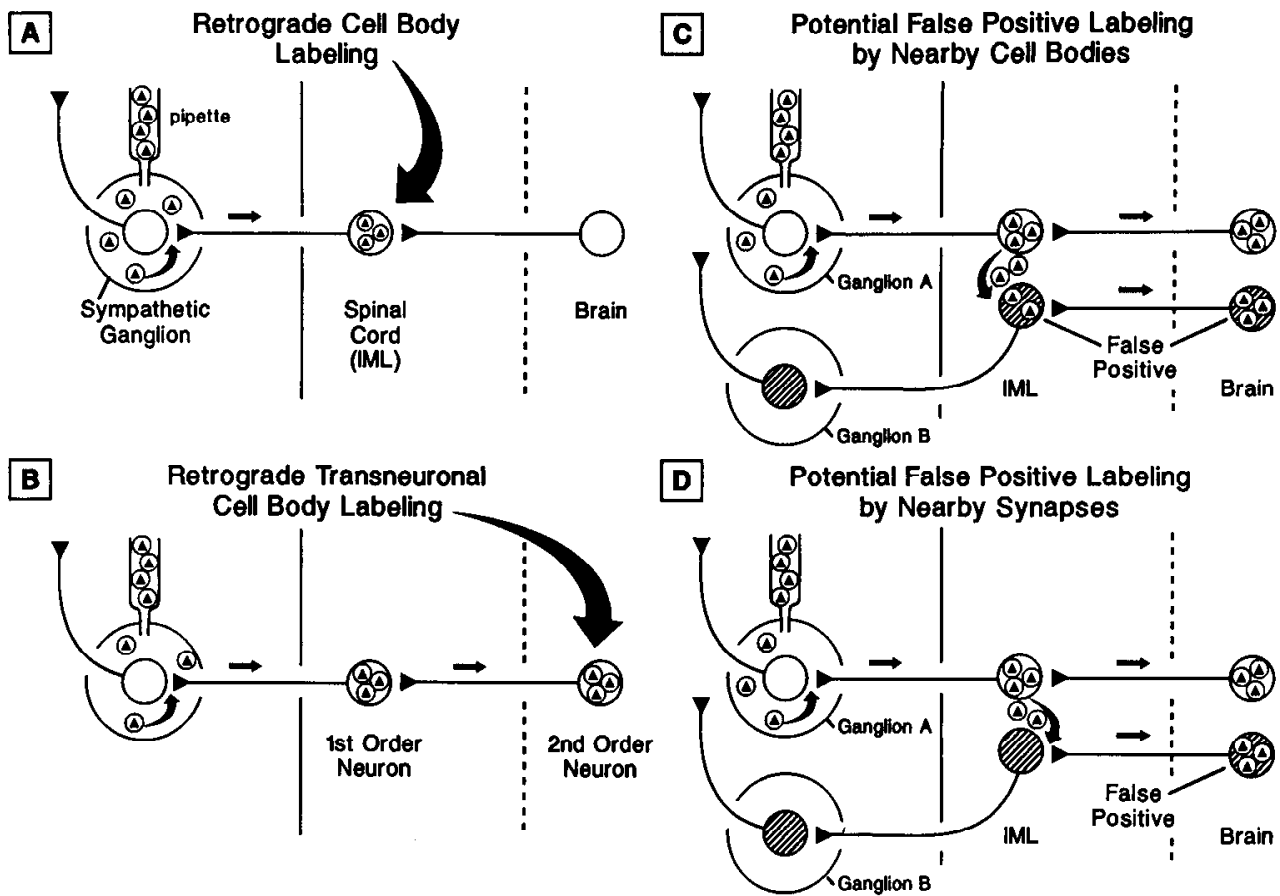

\section{Experiment 1: specificity of PRV uptake by cell bodies}

After sequential PRV and WGA-HRP injections in the anterior chamber of the eye, the pattern of retrograde cell body labeling in the SCG was examined. In 10 out of 12 rats, all of the PRVinfected cells also were labeled with WGA-HRP (Fig. 4). In these experiments, between $\sim 600-1000$ dual labeled cells were found in the SCG. All of the rats had occasional cells that were immunoreactively positive for WGA-HRP but not for PRV. One rat had no PRV labeling in the SCG but did have WGAHRP labeling. In addition, the SCG of another rat had 5 PRV-

\section{Table 1. Number of PRV-infected neurons per spinal segment after} PRV injection of the eye or ear

\begin{tabular}{lccccccc} 
Rat No. & C8 & T1 & T2 & T3 & T4 & T5 & Total \\
\hline \multicolumn{2}{l}{ Eye experiments } & & & & & & \\
996 & 7 & 68 & 55 & 36 & 7 & 1 & 174 \\
1004 & 13 & 259 & 287 & 136 & 41 & 3 & 739 \\
1009 & 14 & 101 & 444 & 385 & 96 & 18 & 1058 \\
1010 & 6 & 117 & 151 & 40 & 3 & 0 & 317 \\
1012 & 8 & 153 & 414 & 155 & 34 & 1 & 765 \\
Average & 9.6 & 139.6 & 270.2 & 150.4 & 36.2 & 4.6 & 610.6 \\
SEM & 1.8 & 36.7 & 83.5 & 70.9 & 18.6 & 3.8 & 179.8 \\
Ear experiments & & & & & & \\
1153 & 1 & 11 & 51 & 152 & 173 & 19 & 407 \\
1198 & 0 & 9 & 164 & 203 & 151 & 216 & 743 \\
1490 & 0 & 3 & 48 & 108 & 198 & 27 & 384 \\
1563 & 1 & 1 & 30 & 333 & 277 & 108 & 750 \\
1586 & 0 & 4 & 28 & 35 & 37 & 23 & 137 \\
1598 & 1 & 1 & 88 & 60 & 26 & 111 & 287 \\
1611 & 0 & 27 & 208 & 541 & 270 & 216 & 1262 \\
Average & 0.4 & 8.0 & 88.1 & 204.6 & 161.7 & 102.8 & 567.1 \\
SEM & 0.2 & 3.8 & 29.5 & 74.4 & 41.8 & 36.0 & 158.6
\end{tabular}

Note: Numbers presented in this table are based on counts taken from every other section cut at $50 \mu \mathrm{m}$ in the horizontal plane. infected cells that lacked WGA-HRP immunoreactivity. The spinal cords of each of the rats (except the one with no PRV labeling in the SCG) had transneuronal cell body labeling in the IML in the same spinal segments as the other PRV eye injection experiments. Thus, these experiments demonstrate no evidence of infection of nearby, but unrelated, ganglion cells at this time point.

\section{Experiment 2: specificity of $P R V$ uptake by synapses}

After PRV injections into either the eye or pinna, the pattern of transneuronal cell body labeling in the spinal cord was studied. The spinal segmental pattern of transneuronal cell body labeling after eye and ear PRV injections was distinct (see Figs. 5,6 ). The majority of the labeling after eye injections was in the T1-T3 spinal segments, while the majority of the labeled spinal neurons after ear injections was found in T2-T5 segments. Table 1 shows the raw data for the number of labeled neurons in each spinal segment present in an alternate series of sections (1-in-2). Relatively large numerical differences were found among the individual rats but when these quantitative data were plotted as the percentages of total infected cells in Figure 5 the results from each experiment were similar. Thus, these experiments indicate that PRV is not taken up by synapses which innervate nearby, but functionally unrelated, cell bodies (Fig. $7 D$ ).

\section{Experiment 3: PRV infections of glial cells}

In most of the SCG and spinal cord material, there was no evidence for glial cell infections with PRV. In extremely rare situations, an occasional GFAP-positive cell was found to contain PRV immunoreactivity. In the great majority of our histological material that contained retrogradely labeled SCG cells or transneuronally labeled sympathetic preganglionic neurons, PRV-infected glial cells were not observed.

\section{Discussion}

The results presented here demonstrate that Bartha's $\mathrm{K}$ strain of PRV may be used as a specific retrograde transneuronal mark- 
er in the sympathetic nervous system. PRV can be also transported in an anterograde direction (Sabin, 1938; Martin and Dolivo, 1983), but none of the experiments performed in this study have dealt with this issue. We have tested for the possibility that the virus is taken up by nearby cell bodies (Fig. 7C) or synapses (Fig. $7 D$ ) and have found no evidence to suggest that false-positive cell body labeling occurs through these structures or through glial cells.

First, PRV injections into the anterior chamber of the eye resulted in retrograde cell body labeling of SCG neurons in exactly the same neurons that were retrogradely labeled with WGA-HRP. This correspondence in PRV and WGA-HRP labeling implies that lateral viral spread to nearby cell bodies does not occur and rules out the idea that nonspecific PRV retrograde cell body labeling occurs in the SCG.

Second, PRV is transneuronally transferred in a specific manner as judged by the segmental specific patterns of IML cell body labeling seen after either the PRV injection of the pinna or the eye. Our anatomical results correlate with the known specific sympathetic outflow patterns of different end organs established by Langley (1892) and Lichtman et al. (1979).

Third, PRV rarely infected glial cells.

\section{Viruses as transneuronal cell body markers}

The overall usefulness of the transneuronal viral transport technique as a general neuroanatomical tool will depend on a number of factors, and it is quite likely that there will be no perfect virus for all neuronal systems and for all species of laboratory animals. With this in mind, it is worth briefly summarizing our earlier experience with Bartha's $K$ strain of $P R V$ as a retrograde transneuronal cell body marker. First, this virus appears to work as an excellent retrograde transneuronal cell body marker in the sympathetic nervous system within a relatively narrow time window of about 3.5-4 d (Strack et al., 1989a). The reason(s) why we could not detect PRV with immunohistochemical methods after postinjection periods of $5 \mathrm{~d}$ or more is not yet clear. It may be a combination of several factors, including the low viral dose used, the possibility that the infection became latent (Hill, 1985), and/or the immune system limited the spread of the virus. Second, Bartha's strain of PRV appears to spread across only 1 or sometimes 2 synapses. The reason for this is unclear. Other herpesviruses, like HSV-1, cross up to 3 or 4 synapses (McLean et al., 1989; Norgren and Lehman, 1989). Potential reasons for the difference in number of synapses crossed may be due to differing properties of the 2 viruses, as well as to differences of viral titers used. In the HSV-1 experiments, the titer used was $10^{9} \mathrm{pfu} / \mathrm{ml}$, whereas in our earlier studies the concentration was $10^{5}$. It is also important to note that the injections of high concentrations of $\mathrm{HSV}-1$ also resulted in neuronal lysis and uptake of virus by glial cells (Ugolini et al., 1987; McLean et al., 1989). In contrast, we found that low doses of PRV rarely caused neuronal destruction and failed to infect glial cells. This leads us to hypothesize that there may be an optimal viral concentration needed to obtain infections of specific chains of synaptically related neurons. However, this may not be explained entirely by concentration differences. In our experience, wild-type PRV-infected neurons are much more prone to cell lysis than those infected with Bartha's PRV. Thus, the properties of the virus are also a significant factor.

Our reason for using Bartha's $K$ strain of PRV is that we can get specific transneuronal viral labeling without compromising the health of the rat. Rats showed no ill-effects following injec- tions of Bartha's strain of PRV into the sympathetic ganglia or adrenal gland (see Strack et al., 1989a). In contrast, wild-type PRV caused severe infections in rats and resulted in death within $3 \mathrm{~d}$. In addition, the infections often became widely disseminated throughout the CNS. One drawback is that we observed a relatively low success rate $(20 \%)$ with Bartha's PRV as a viral cell body marker (Strack et al., 1989a, b). This may be the result of 1 or more of 3 factors as discussed above: viral concentration, attenuated strain of virus, and variability of the immune response (Lopez, 1975, 1980).

An important issue that may determine the overall usefulness of the viral retrograde transneuronal method as a neuroanatomical tool is whether viruses are taken up by fibers of passage and/or cut axons. Ugolini et al. (1987, 1989) observed that following $\mathrm{HSV}-1$ injections into the peripheral nerves, retrograde cell body and retrograde transneuronal cell body labeling occurred in numerous CNS sites. Whether PRV acts in a similar way is still unsettled. If Bartha's strain of PRV is demonstrated to be taken up by fibers of passage, it will mean that when this method is used in neuroanatomical studies, as with most other tract tracing markers, additional correlative anatomical experiments will be necessary. Specifically, the anterograde axoplasmic transport method (e.g., PHA-L method) and electron microscopy will have to be performed. While this potential limitation may detract from the power of this method, the fact that it can be combined with any other standard immunohistochemical procedure adds a new tool for neuroanatomical studies. Also, it may be possible to produce molecular modifications of the PRV or other viruses to produce strains that have the desired biological properties.

That herpesviruses can be taken up by and transported along peripheral nerves to the CNS has been known for over 50 years (Goodpasture and Teaguc, 1923; Hurst, 1933). Hurst (1933) demonstrated that an animal given PRV subcutaneously, intradermally, or intramuscularly will first get an infection in that region, then an infection in the corresponding dorsal root ganglion, and then an infection in the portion of the spinal cord corresponding to the dermatome infected, and finally an infection in the brain. Early investigators concluded that the route of transmission through nerves was primarily in the Schwann cells (Rabin et al., 1968; Severin and White, 1968), but more recent studies have shown specific binding of HSV and PRV to viral receptors on neurons (Vahlne et al., 1978, 1980; Ziegler and Pozos, 1981; Marchand and Schwab, 1986). Others have also demonstrated that viruses are transported mainly in axons (Kristensson, 1970; Kristensson et al., 1971; Cook and Stevens, 1973; Field and Hill, 1974, 1975; Marchand and Schwab, 1986).

Herpesviruses (HSV-1 and PRV) and rabies virus have been the only viruses to date uscd for neuroanatomical studies (for references, see introductory remarks) because they primarily infect neurons and have a relatively low affinity for glial cells and brain endothelial cells. Neurotropic viruses exhibit tropisms for specific classes of neurons, and this may limit any single virus in its overall usefulness as a general neuroanatomical tool (see below for further discussion). This differential susceptibility to infection could be due to variations in viral attachment sites on neurons, as well as to differences of internal cellular factors.

Viruses are taken up into neurons by the result of binding of a viral attachment protein to specific molecules on the surface of the neuronal membrane that act as viral receptors (see Tyler, 1987a, b; Tyler and McPhee, 1987; and Lentz, 1988, for reviews). $P R V$ is thought to bind to a glycoprotein in axon ter- 
minals which can be displaced by concanavalin A (Marchand and Schwab, 1986). HSV-1 binding is also thought to be a glycoprotein-mediated event because it is displaced by WGA, which binds $N$-acetyl- $\beta$-D-glucosaminyl residues and is eliminated when the cells are treated with neuraminidase, suggesting that HSV - 1 binds to a carbohydrate moiety (Ziegler and Pozos, 1981). Whether this blockade of infection is the result of binding to specific reccptor(s) or to a lectin-induced change in the cell membrane is not established. These viral attachment sites are thought to be present mainly on neurons. This idea stems from work by Vahlne et al. (1980), who showed that the binding affinity of HSV is higher in synaptosome fractions than in homogenates of glia or neuronal cell bodies.

Neurotropic viruses exhibit tropisms for specific classes of neurons. This was first demonstrated by Sabin (1938), who studied the neuroinfectivity of 3 different viruses - pseudorabies virus, vesicular stomatitis virus, and equine encephalomyelitis virus. Only PRV caused infections of the trigeminal, sympathetic, and parasympathetic pathways. It did not infect the olfactory system, whereas vesicular stomatitis and equine encephalomyelitis viruses selectively infected this system. Similarly, Martin and Dolivo (1983) did not observe PRV labeling in the mesencephalic nucleus of the trigeminal nerve after masseter muscle injections, cven though this nucleus provides an innervation of the muscle spindles of this particular muscle. Because other trigeminal pathways were labeled, these negative results suggest that some neurons have specialized receptors for PRV and others do not. This may mean PRV cannot be used as a universal transneuronal marker.

Other neurotropic viruses could potentially be used as transneuronal markers, but these also exhibit specific tropisms for particular classes of neurons. For example, rabies is transported in both anterograde and retrograde directions and transneuronally infects multiple visual pathways (Kucera et al., 1985). It was shown that the virulent CVS strain of rabies virus enters the CNS via retinofugal pathways and retrogradely via the parasympathetic pathway but not by the trigeminal system or the sympathetic pathways. The avirulent strain tested, which had a mutation of a viral glycoprotein, infected the trigeminal ganglion but not the CNS.

Most strains of poliovirus infect only primates and, thus, for general neuroanatomical studies this virus would not be ideal. However, there are some strains of human poliovirus (e.g., the Lansing type 2 poliovirus) that are capable of infecting mice. This strain, though, seems to have a high affinity for neurons of the motor system, as do the other strains of human poliovirus (Jubelt et al., 1980); thus, the tropism of this virus may restrict its general usefulness.

In summary, our results show that Bartha's strain of PRV can be used as a specific retrograde transneuronal marker. The primary limitation of this viral transneuronal labeling method relates to the inherent properties of viruses. PRV, however, seems to have fewer limitations than other viruses and should prove to be an extremely promising tool for neuroanatomical studies.

\section{References}

Cook ML, Stevens JG (1973) Pathogenesis of herpetic neuritis and ganglionitis in mice: evidence for intra-axonal transport of infection. Infect Immunol 7:272-288.

Evinger C, Erichsen JT (1986) Transsynaptic retrograde transport of fragment $\mathrm{C}$ of tetanus toxin demonstrated by immunohistochemical localization. Brain Res 380:383-388.
Field HJ, Hill TJ (1974) The pathogenesis of pseudorahies in mice following peripheral inoculation. J Gen Virol 23:145-157.

Field HJ, Hill TJ (1975) The pathogenesis of pseudorabies in mice: virus rcplication at the inoculation site and axonal uptake. J Gen Virol 26:145-148.

Goodpasture EW, Teague O (1923) Experimental production of herpetic lesions in organs and tissues of the rabbit. J Med Res 44:121138 .

Gustafson DP (1975) Pseudorabies. In: Diseases of swine (Leman AD et al., eds), pp 209-223. Ames, IA: Iowa State U.P.

Hill TJ (1985) Herpes simplex virus latency. In: The herpes viruses, Vol 3 (Roizman B, ed), pp 175-240. New York: Plenum.

Hurst EW (1933) Studies on pseudorabies (infectious bulbar paralysis, mad itch). I. Histology of the disease, with a note on the symptomatology. J Exp Med 58:415-433.

Irie H, Harada Y, Kurokawa E, Saito M, Sugawara Y, Ohami H, Mori W (1987) Early adrenal infection by herpes simplex virus type-1 (Miyama + GC strain): spccial reference to inoculation dose and spread from the adrenal to the central nervous system. Virchows Arch B 53:325-331.

Irie H, Harada Y, Yoshihashi H, Kimura T, Kojima M, Kataoka M, Saito M, Sugawara Y, Mori W (1989) Spread of herpes simplex virus type-1 (Miyama + GC strain) to the central nervous system after intraperitoneal inoculation: the role of the myenteric plexus of the gut. Arch Virol 105:247-257.

Jubelt B, Gallez-Hawkins G, Narayan O, Johnson RT (1980) Pathogenesis of human poliovirus infection in mice. I. Clinical and pathological studies. J Neuropathol Exp Neurol 39:138-148.

Kristensson K (1970) Morphological studies of the neural spread of herpes simplex virus to the central nervous system. Acta Neuropathol 16:54-63.

Kristensson K, Lycke E, Sjostrand J (1971) Spread of herpes simplex virus in peripheral nerves. Acta Neuropathol 17:44-53.

Kristensson K, Nennesmo I, Persson L, Lycke E (1982) Neuron to neuron transmission of herpes simplex virus. Transport of virus from skin to brainstem nuclei. J Neurol Sci 54:149-156.

Kucera P, Dolivo M, Coulon P, Flamand A (1985) Pathways of the early propagation of virulent and avirulent rabies strains from the eye to the brain. J Virol 55:158-162.

Langley JN (1892) On the origin from the spinal cord of the cervical and upper thoracic sympathetic fibres, with some observations on white and grey rami communicantes. Phil Trans R Soc Lond [Biol] $183: 85-124$.

Lentz TL (1988) Binding of viral attachment protein to host-cell receptor: the Achilles heel of infectious viruses. Trends Pharm Sci 9: 247-252.

Lichtman JW, Purves D, Yip JW (1979) On the purpose of selective innervation of guinea-pig superior cervical ganglion cells. J Physiol (Lond) 292:69-84.

Lopez C (1975) Genetics of natural resistance to herpesvirus infections in mice. Nature 258:152-153.

Lopez C (1980) Resistance to HSV-1 in the mouse is governed by two major, independently segregating, non-H-Z loci. Immunogen 11:8792.

Marchand CF, Schwab ME (1986) Binding, uptake and retrograde axonal transport of herpesvirus suis in sympathetic neurons. Brain Res 383:262-270.

Martin X, Dolivo M (1983) Neuronal and transneuronal tracing in the trigeminal system of the rat using the herpesvirus suis. Brain Res 273:253-276.

McLean JH, Shipley MT, Bernstein DI (1989) Golgi-like, transneuronal retrograde labelling with CNS injections of herpes simplex virus type-1. Brain Res Bull 22:867-881.

Mravik S, Bienzle O, Feldmeier H, Hampl H, Habermehl K-C (1987) PRV in man. Lancet 1:501-502.

Njả A, Purves D (1977) Specific innervation of guinea-pig superior cervical ganglion cells by preganglionic fibres arising from different levels of the spinal cord. J Physiol (Lond) 264:565-583.

Norgren RB, Lehman MN (1989) Retrograde transneuronal transport of herpes simplex virus in the retina after injection in the superior colliculus, hypothalamus and optic chiasm. Brain Res 479:374-378.

Platt KB, Maré CJ, Hinz PN (1979) Differentiation of vaccine strains and field isolates of pseudorabies (Aujeszky's Disease) virus: thermal sensitivity and rabbit virulence markers. Arch Virol 60:13-23.

Rabin ER, Jenson AB, Melnick JL (1968) Herpes simplex virus in mice: electron microscopy of neural spread. Science 162:126-127. 
Ranscht B, Clapshaw PA, Price J, Noble M, Seifert W (1982) Development of oligodendrocytes and Schwann cells studied with a monoclonal antibody against galactocerebroside. Proc Natl Acad Sci USA 79:2709-2713.

Rouiller EM, Capt M, Dolivo M, De Ribapierre F (1986) Tensor tympani reflex pathways studied with retrograde horseradish peroxidase and transneuronal viral tracing techniques. Neurosci Lett 72: 247-252.

Rouiller EM, Capt M, Dolivo M, De Ribapierre F (1989) Neuronal organization of the stapedius reflex pathways in the rat: a retrograde HRP and viral transneuronal tracing study. Brain Res 476:21-28.

Sabin AB (1938) Progression of different nasally instilled viruses along different nervous pathways in the same host. Proc Soc Exp Biol Med 38:270-275.

Severin MJ, White RJ (1968) The neural transmission of herpes simplex virus in mice. Light and electron microscopic findings. Am J Pathol 53:1009-1020.

Spatz WB (1989) Differences in transneuronal transport of horseradish peroxidase conjugated wheat germ agglutinin in the visual system: marmoset monkey and guinea pig compared. I. Hirnforsch 30:375384.

Spencer SE, Sawyer WB, Platt KB, Loewy AD (1990) CNS projections to pterygopalatine preganglionic neurons in the rat: a retrograde transneuronal viral cell body labelling study. Brain Res (in press).

Strack AM, Sawyer WB, Platt KB, Loewy AD (1989a) CNS cell groups regulating the sympathetic nervous outflow to adrenal gland as revealed by transneuronal cell body labeling with pseudorabies virus. Brain Res 491:274-296.

Strack AM, Sawyer WB, Hughes JH, Platt KB, Loewy AD (1989b) A general pattern of CNS innervation of the sympathetic outflow demonstrated by transneuronal pseudorabies viral infections. Brain Res $491: 156-162$.
Thomander L, Aldskogius H, Vahlne A, Kristensson K, Thomas E (1988) Invasion of cranial nerves and brain stem by herpes simplex virus inoculated into the mouse tongue. Ann Otol Rhinol Laryngol 97:554-558.

Tyler, KL (1987a) Host and viral factors that influence viral neurotropism. 1. Viral cell attachment proteins and target cell receptors. Trends Neurosci 10:455-460.

Tyler KL (1987b) Host and viral factors that influence viral neurotropism. II. Viral genes, host genes, site of entry and route of spread of virus. Trends Neurosci 10:492-497.

Tyler KL, McPhee DA (1987) Molecular and genetic aspects of the pathogenesis of viral infections of the ccntral ncrvous systcm. CRC Crit Rev Neurobiol 3:221-243.

Ugolini G, Kuypers HGJM, Simmons A (1987) Retrograde transneuronal transfer of herpes simplex virus type 1 (HSV-1) from motoneurones. Brain Res 422:242-256.

Ugolini G, Kuypers HGJM, Strick PL (1989) Transneuronal transfer of herpes virus from peripheral nerves to cortex and brainstem. Science 243:89-91.

Vahlne A, Nystrom B, Sandberg M, Hamberger A, Lycke E (1978) Attachment of herpes simplex virus to neurons and glial cells. J Gen Virol 40:359-371.

Vahlne A, Svennerholm B, Sandberg M, Hamberger A, Lycke E (1980) Differences in attachment between herpes simplex type 1 and type 2 viruses to neurons and glial cells. Infect Immunol 28:675-680.

Wesselingh SL, Li YW, Blessing WW (1989) PNMT-containing neurons in the rostral medulla oblongata $(\mathrm{Cl}, \mathrm{C} 3$ groups) are transneuronally labelled after injection of herpes simplex virus type 1 into the adrenal gland. Neurosci Lett 106:99-104.

Ziegler RJ, Pozos RS (1981) Effects of lectins on peripheral infection by herpes simplex virus of rat sensory neurons in culture. Infect Immunol 34:588-595. 